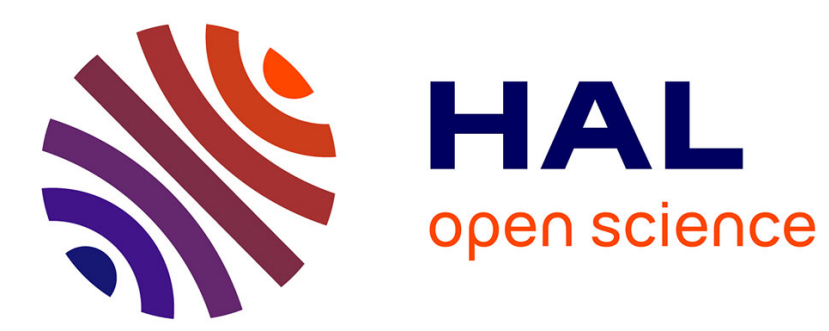

\title{
The Arrest of Victor Vassiliev
}

Alexander Shen

\section{To cite this version:}

Alexander Shen. The Arrest of Victor Vassiliev. 2014, pp.1-2. 10.1007/s00283-014-9478-9 . lirmm01345481

\section{HAL Id: lirmm-01345481 https://hal-lirmm.ccsd.cnrs.fr/lirmm-01345481}

Submitted on 7 Jun 2019

HAL is a multi-disciplinary open access archive for the deposit and dissemination of scientific research documents, whether they are published or not. The documents may come from teaching and research institutions in France or abroad, or from public or private research centers.
L'archive ouverte pluridisciplinaire HAL, est destinée au dépôt et à la diffusion de documents scientifiques de niveau recherche, publiés ou non, émanant des établissements d'enseignement et de recherche français ou étrangers, des laboratoires publics ou privés. 


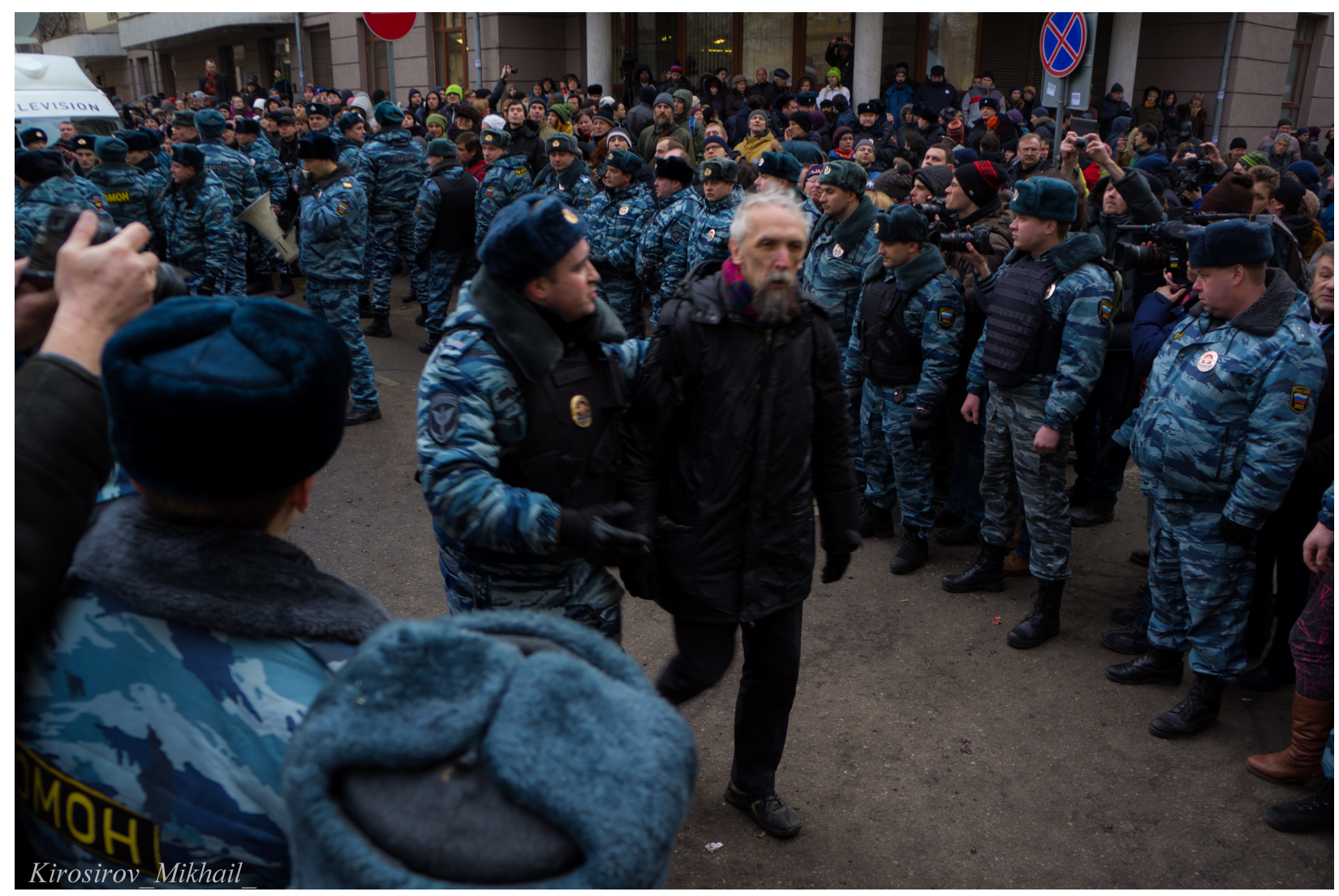

Figure 1: The arrest of the President of the Moscow Mathematical Society V.A. Vassiliev, member of the Russian Academy of Sciences, by Moscow riot police, February 24, 2014. Photo by Mikhail Kirosirov.

\section{Dear Editor,}

This photo (Figure 1) shows the arrest of Victor Vassiliev, known to mathematicians for Vassiliev invariants in knot theory, by Moscow riot police on February 24, 2014. Professor Vassiliev was released after a few hours and later convicted and fined. Readers of The Mathematical Intelligencer may have already heard about this, and may have even have seen this photo. The European Mathematical Society and the President of the American Mathematical Society, David Vogan, have made statements in his support. ${ }^{1}$ I write to provide the context.

In 2011 the ruling party in Russia ("Edinaya Rossiya") won a majority of seats in the Russian "parliament" ("Gosduma") according to the official "election" results. Many people, however, complained about electoral fraud. That's not unusual, of course; but it is interesting that this time the anectodal evidence was corroborated by official election statistics (which were carelessly made public). The troubling pattern is easy to see on the histogram (Figure 2 that Dmitry Kobak ${ }^{2}$ made on December 12, 2011, about a week after the "elections"). The histogram shows sharp peaks at multiples of 5 and 10. It is hard to imagine any

\footnotetext{
${ }^{1}$ http://www.ams.org/news/vogan-vasilliev-letter.pdf, http://www . euro-math-soc.eu/node/4575

${ }^{2}$ http://kobak.livejournal.com
} 


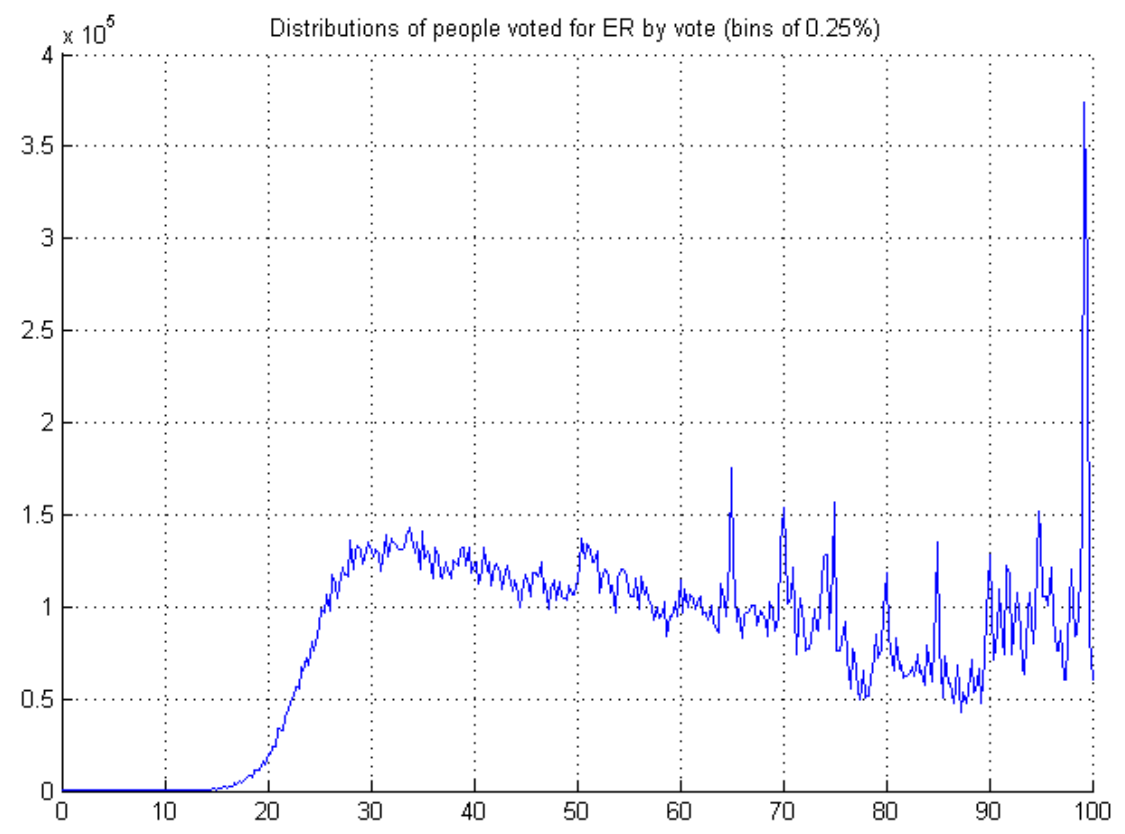

Figure 2: The histogram shows, for each interval of size $0.25 \%$, the number of votes for the ruling party ('Edinaya Rossia') that—according to the official version—were cast at the polling stations where the result of this party belongs to that interval.

explanation for these peaks other thans falsified counting. ${ }^{3}$

This evidence, together with general disgust, triggered protests in the following months, and a large demonstration took place on May 6, 2012. The demonstration led to some clashes with the police, e.g., some plastic street toilets were overturned and damaged. Several people were arrested and recently, after more than a year in prison, were convicted for participating in a "riot" ("massovye besporyadki" in Russian. Never mind that the Russian ombudsman V. Lukin (a reasonably decent person usually ignored by the authorities) witnessed this demonstration and noted in his official statement ${ }^{4}$ that the riot claim was false.

Nevertheless, several people were sentenced, among them 52 year old Sergey Krivov. ${ }^{5}$ At the trial Krivov, who went on a hunger strike to defend his procedural rights, got a 4-year sentence. According to the prosecutors, he had grabbed a baton from one of the policemen, bruised the hand of another, and pushed third with both hands. Krivov says a policemen started to beat him and he defended himself. ${ }^{6}$

The verdict of this trial was to be announced at the "public court hearing" February 24, 2014. Many people, including V.V., came to show their moral support to the hostages. However, the hearing was held in

\footnotetext{
${ }^{3}$ See: Günther M. Ziegler, Mathematik - Das ist doch keine Kunst!, chapter "2012. Gauß in Russland” and the references therein.

${ }^{4}$ http://www .ombudsmanrf .org/zayavleniya/723-6-2012

${ }^{5}$ Krivov's $\mathrm{PhD}$ thesis concerned low energy $\gamma$-radiation at the MIR space station, measured using high pressure xenon spectrometer; the related paper was published as 10.1109/NSSMIC.1996.591006.

${ }^{6}$ see, e.g., http://rosuznik.org/arrests/SergKrivov and http://6may.org/wp-content/uploads/2014/02/Digest25Feb03-09.pdf.
} 
a small room and these people were not allowed in. While they waited outside the court building (some shouted slogans, but the only violence was the arrests made by the riot police), several hundred of them, including V.V., were detained and later convicted and fined.

I was not brave enough to go there; however, I did attend V.V.'s own trial in the same "court". Four people were convicted at this hearing; all four were found guilty of participating in an illegal gathering, resisting the police and shouting slogans. They were fined (10000 roubles, around $\$ 300$ at the current rate). The two witnesses in V.V.'s case (including V.V. Prasolov, the author of several textbooks ${ }^{7}$ ) confirmed that V.V. stood silent when arrested and did not resist. Still both charges remained in the verdict. To explain the atmosphere, let me also note that another defendant cited the statement of Russian ombudsman V. Lukin who wrote that "now the police tactics looks as follows: a group of policemen grabs arbitrarily chosen people, sometimes just passing by" ${ }^{8}$, again with no effect. This defendant also claimed, and the claim was confirmed by the witness, that he was detained in a completely different place (another gathering on the same date), but the verdict still gave the same address as the three others. When the defendant asked permission to question the policeman who signed the police report, the "judge" said that since the defendant did not bring the policeman into the court, the request is denied. And so on: seemingly, the goal of the "judge" was to demonstrate that no arguments would be taken into account.

I hope that these comments may help the readers of The Mathematical Intelligencer to better understand the current situation in Russia.

Sincerely yours, Alexander Shen

${ }^{7}$ http://www . amazon.com/V.-V.-Prasolov/e/B001JSB68M.

${ }^{8}$ http: //ombudsmanrf .org/zayavleniya/7237-20140304z, section 4. 